\title{
Impaired Gap Junction Connexin43 in Sertoli Cells of Patients with Secretory Azoospermia: A Marker of Undifferentiated Sertoli Cells
}

\author{
Norah Defamie, Isabelle Berthaut, Baharia Mograbi, Daniel Chevallier, \\ Jean-Pierre Dadoune, Patrick Fénichel, Dominique Segretain, and Georges Pointis \\ INSERM EMI 00-09 (ND, BM, DC, PF, GP), IFR 50, Faculté de Médecine, Nice Cedex, and Université Paris V (DS), \\ Paris, and Groupe d'Etude de la Formation et de la Maturation du gamète mâle (IB, J-PD), Laboratoire de Cytologie \\ et d'Histologie, UFR Biomédicale, Paris, France
}

SUMMARY: Gap junctions are intercellular channels formed of connexins (Cx) at appositional plasma membranes between adjacent cells that have been involved in the control of cell proliferation and differentiation. Altered Cx expression is implicated consistently in several human diseases and in tumorigenesis. Although Cx43 plays a critical role in Sertoli cell control of spermatogenesis, there is no evidence of its altered expression in human testicular pathologies. We show here that Cx43 mRNA expression was significantly reduced in testes of infertile patients with secretory azoospermia $(p<0.05)$ compared with testes displaying normal spermatogenesis (excretory azoospermic patients). In Sertoli cell-only syndrome, in situ hybridization and immunohistochemistry analyses indicated that Cx43 mRNA and protein were undetectable in Sertoli cells but were still present in the interstitial compartment. In a rat model of Sertoli cell-only syndrome, the lack of Cx43 in Sertoli cells was associated with an impairment of gap junction intercellular communication between adjacent Sertoli cells. These results reveal that Cx43 mRNA and protein expression are markedly impaired in Sertoli cells of infertile patients. This defect could be a new functional marker of undifferentiated Sertoli cells and could be related to the increased risk of testicular cancer recently described in the population of infertile men. (Lab Invest 2003, 83:449-456).

G ap junctions are clusters of channels, formed of proteins termed connexins (Cx), which allow the intercellular exchange of small signaling molecules $(<1 \mathrm{kDa})$ between the cytoplasmic compartments of two adjacent cells (for review, see Goodenough et al, 1996). Gap junctional intercellular communication (GJIC) is essential to the regulation of cellular growth, differentiation, and tissue homeostasis (for review, see Kumar and Gilula, 1996). Mutations in Cx genes underlie a variety of human diseases, such as demyelinating neuropathies, deafness, and lens cataracts (White and Paul, 1999). Likewise, tumorigenesis is correlated with impaired GJIC and loss of Cx expression (Trosko and Ruch, 1998), and transfection of Cx has been reported to restore normal phenotype in vitro and reduce tumor growth in vivo (Omori et al, 2001).

In the testis, Cx43 is the most expressed Cx (Risley et al, 1992) and is mainly present within the seminif-

\section{DOI: 10.1097/01.LAB.0000059928.82702.6D}

Received October 28, 2002.

The two first authors contributed equally to this work. This research was supported in part by the Ligue Nationale contre le Cancer and by Association pour la Recherche contre le Cancer (Grant 98-80). ND was supported by grants from the Agence de l'Environnement et de la Maîtrise de l'Energie and BM was supported by grants from the Fondation Fertilité Stérilité and Organon.

Address reprint requests to: Dr. G. Pointis, INSERM EMI 00-09, IFR 50, Faculté de Médecine, Avenue de Valombrose, 06107 Nice Cedex 2, France. E-mail:pointis@unice.fr erous tubules in Sertoli cells (Batias et al, 2000; Risley et al, 1992). The notion that $\mathrm{Cx} 43$ is absolutely required for the control of spermatogenesis comes from the recent demonstration that $\mathrm{C} \times 43$ gene-targeted deletion in mice results in male infertility (Juneja et al, 1999; Plum et al, 2000). In this context, analysis of Cx43 expression in infertile men is of particular interest because it has been suggested that infertility and subfertility constitute relative risk of testicular cancer development (Moller and Skakkebaek, 1999). However, only sparse observations have been reported for the presence of gap junctions and $\mathrm{C} \times 43$ in pathologic human testes (Bigliardi and Vegni-Talluri, 1977; Cavicchia et al, 1996; Nagano and Susuki, 1976; Steger et al, 1999).

In the present study, we analyzed $\mathrm{Cx} 43$ gene and protein expression by semiquantitative RT-PCR, in situ hybridization, and immunohistochemistry in testicular biopsy specimens from infertile patients with secretory azoospermia. We show that $\mathrm{C} \times 43$ expression is impaired in Sertoli cells of this patient population, indicating that this defect could be a marker of undifferentiated Sertoli cell functionality.

\section{Results \\ Testicular Cx43 mRNA Level in Infertile Patients with Secretory Azoospermia}

Cx43 mRNA expression was first analyzed in human testicular biopsy specimens by semiquantitative RT- 
PCR using an endogenous standard, glyceraldehyde3-phosphate dehydrogenase (GAPDH) mRNA. To accurately compare levels of Cx43 mRNA in several patients, we first determined whether the detection of the Cx43 PCR products showed a linear increase in signal intensity. Second, we set up the cycle numbers at which GAPDH primers were added to the PCR mixture. As shown in Figure 1A, the rates of amplification were exponential between 23 and 27 (Lanes 3 and 7 , respectively) cycles for both sets of primers, after the addition of GAPDH primers at the eighth

A

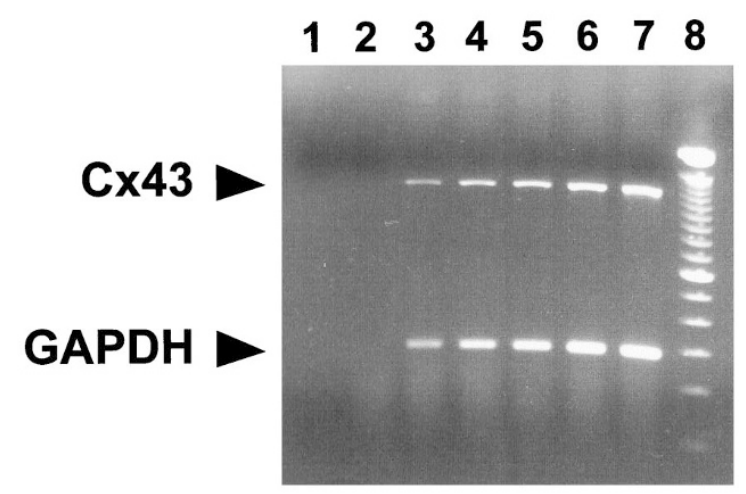

B

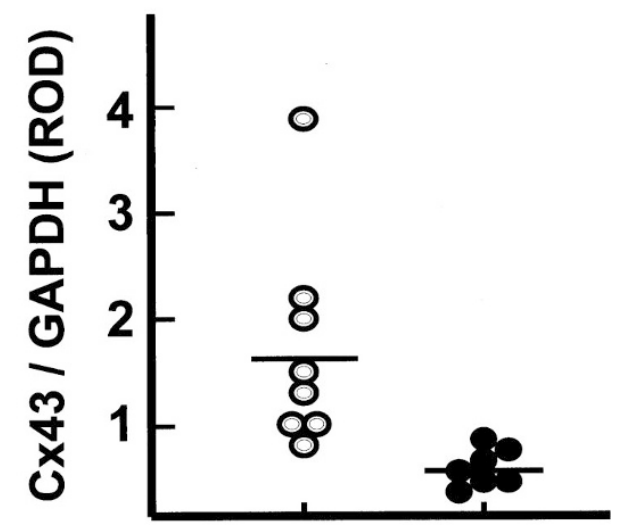

Figure 1.

Testicular expression of connexin43 (Cx43) mRNA in two groups of patients with normal or altered spermatogenesis. A, Cx43 mRNA expression was analyzed in testicular biopsy specimens by semiquantitative RT-PCR using an endogenous standard, glyceraldehyde-3-phosphate dehydrogenase (GAPDH) mRNA. The PCR products of Cx43 (1158 bp) and GAPDH (275 bp) are indicated by arrowheads. Comparisons between Cx43 and GAPDH PCR products were made at 23 (Lane 3), 24 (Lane 4), 25 (Lane 5), and 26 cycles (Lane 6), before the respective amplification reactions reached the plateau phase (Lane 7). Lane 1, negative control $\left(\mathrm{H}_{2} \mathrm{O}\right.$ instead of cDNA); Lane 2, without RT; Lane 8, a 100-bp DNA ladder was used for size analysis. Representative of three independent experiments. B, Testicular Cx43 mRNA in patients with histologically normal spermatogenesis (excretory azoospermia; open circles, $n=8$ ) or with altered spermatogenesis (secretory azoospermia; closed circles, $n=7$ ). Each value represents the ratio of relative optical densities of $\mathrm{C} \times 43$ to GAPDH. Mean values are indicated by horizontal bars. Values between excretory and secretory azoospermic patients are significantly different $(p<0.05)$. cycle. Comparisons between Cx43 and GAPDH PCR products were made at $23,24,25$, and 26 cycles, before the respective amplification reactions reached the plateau phase. No PCR product was detected when cDNA was omitted (Fig. 1A, Lane 1) or in the absence of the reverse transcriptase (Fig. 1A, Lane 2).

Densitometric analyses of Cx43 mRNA levels to GAPDH mRNA were performed to quantify relative changes in Cx43 mRNA expression in testicular tissues presenting partial (presence of spermatogonia) or total (Sertoli cell-only [SCO] syndrome) spermatogenesis failure. As shown in Figure 1B, Cx43 mRNA was detected in all human testicular biopsy specimens with normal (excretory azoospermia) or altered (secretory azoospermia) spermatogenesis. The relative expression of testicular Cx43 mRNA was significantly reduced in the group of patients with altered spermatogenesis compared with men with histologically verified normal spermatogenesis $(p<0.05)$. Of the eight biopsy specimens analyzed in the latter population, the expression of $\mathrm{Cx} 43$ compared with GAPDH was more scattered. This variation of $\mathrm{Cx} 43$ mRNA expression may be explained by the cellular heterogeneity of the testicular biopsy specimens in this group (seminiferous tubules at different stages of spermatogenesis). Inversely, in the group of patients with impaired spermatogenesis, the expression of Cx43 mRNA was low and similar whatever the degree of alteration of spermatogenesis.

\section{Localization of Cx43 Expression in Seminiferous Tubules with Characteristics of SCO Syndrome}

In situ hybridization experiments were performed to analyze the altered expression of Cx43 mRNA in relation to its cellular distribution within seminiferous tubules. Dark-field and bright-field images demonstrate a high accumulation of silver grains at the base of seminiferous tubules and in the interstitial compartment of human testis with normal spermatogenesis (Fig. 2, A and B). As indicated in Figure 2D, Cx43 mRNA was present in Sertoli cells (inset) and in basally located germ cells. In testes with SCO syndrome, the hybridization signal was markedly impaired in seminiferous tubules, whereas it was maintained in the interstitial compartment (Fig. 2E). High magnification shows that silver grains were barely detectable in Sertoli cells of patients with SCO syndrome (Fig. 2E, inset) as compared with control testis (Fig. 2D, inset). Control sections incubated with the sense probe revealed a low nonspecific hybridization signal (Fig. 2C). Semiquantitative analysis indicated that the number of silver grains was significantly decreased by $83 \pm 5 \%$ in Sertoli cells of patients with altered spermatogenesis, as compared with control testis $(p<0.01)$.

Accordingly, immunoreactive staining for $\mathrm{Cx} 43$ protein was observed in all tubules of patients with normal germ cell maturation (data not shown). High magnification indicated that the $\mathrm{Cx} 43$ immunoreactive signal was located in the basal compartment of seminiferous tubules (Fig. 3A). In contrast, no Cx43 was detected in seminiferous tubules of infertile patients with SCO 

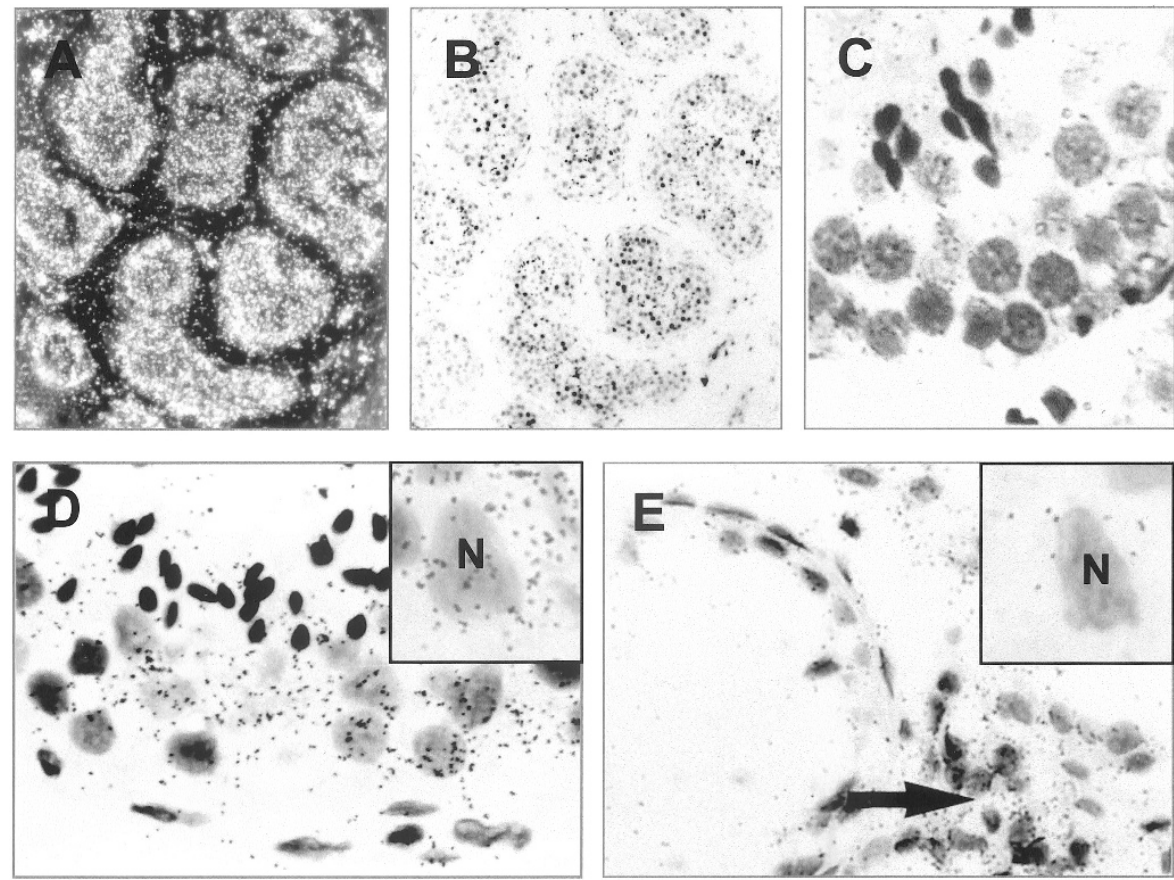

\section{Figure 2.}

Localization of CX43 mRNA in human testis with histologically normal spermatogenesis (control) or with characteristics of Sertoli cell-only (SCO) syndrome. (A) Dark-field and (B) bright-field micrographs of control testis section hybridized with ${ }^{35}$ S-labeled antisense Cx43 RNA probe. Cx43 mRNA is detected within the seminiferous tubules and in the interstitial compartment. D, Higher magnification of bright-field micrographs shows that the hybridization signal is mainly present in Sertoli cells (inset) and in basally located germ cells. E, In seminiferous tubules with characteristics of SCO syndrome, Cx43 mRNA are dramatically impaired in Sertoli cells (inset) but are still present in the interstitial compartment (arrows). Sertoli cells have been identified by the typical appearance of their nucleus ( $M$ ). C, A low nonspecific hybridization signal is barely detectable with the sense CX43 RNA probe.
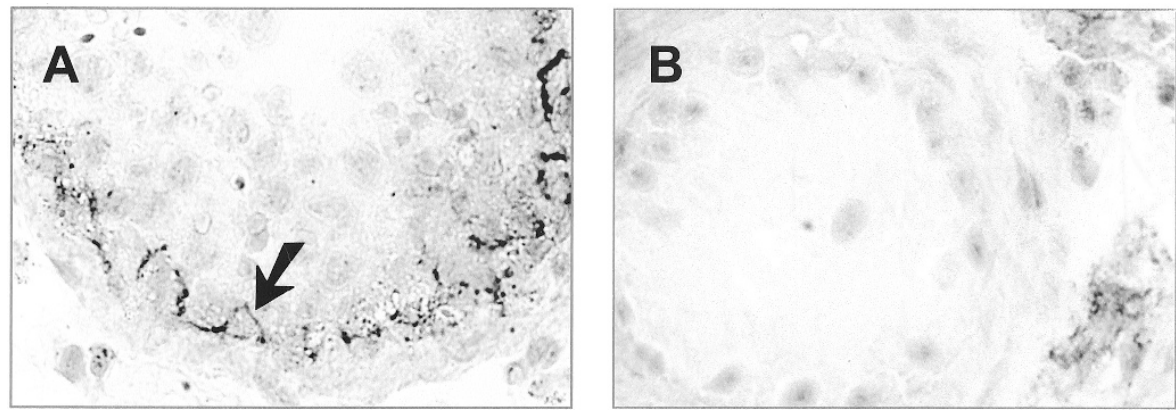

Figure 3.

Cx43 immunolocalization in human testis with histologically normal spermatogenesis (control) or with characteristics of SCO syndrome. A, In control testis, Cx43 immunostaining is located in the basal compartment of seminiferous tubules (arrow). B, In seminiferous tubules with characteristics of SCO syndrome, CX43 protein is undetectable but is still present in the interstitial compartment.

syndrome (Fig. 3B). A spotty signal was still present in the interstitial compartment. No immunoreactivity could be detected in testicular sections incubated without the primary antibody or with nonimmune IgG (data not shown).

\section{Coupling in SCO Seminiferous Tubules}

Dye-coupling experiments were performed to determine whether gap junctional coupling correlated with Cx43 expression within the seminiferous epithelium. Because of the limited size of human testicular biopsy specimens, this approach has been developed in unilateral cryptorchid Long-Evans mutant rats with abdominal testes displaying characteristics of SCO syndrome. Consistent with the above data in humans, in situ hybridization analysis indicated that Cx43 transcripts were mainly detected within the seminiferous tubules in Sertoli cells of scrotal testis with normal spermatogenesis (Fig. 4A). In contrast, the hybridization signal was no longer detected in Sertoli cells of tubules showing characteristics of SCO syndrome (Fig. 4B). Silver grains were, however, present in the interstitial compartment. In seminiferous tubule sections from testis with normal spermatogenesis identified by 4,6-diamidino-2-phenylindole (DAPI) staining (Fig. 4C), dextran-rhodamine fluorescence was detected in two Sertoli cells injured by cutting and 

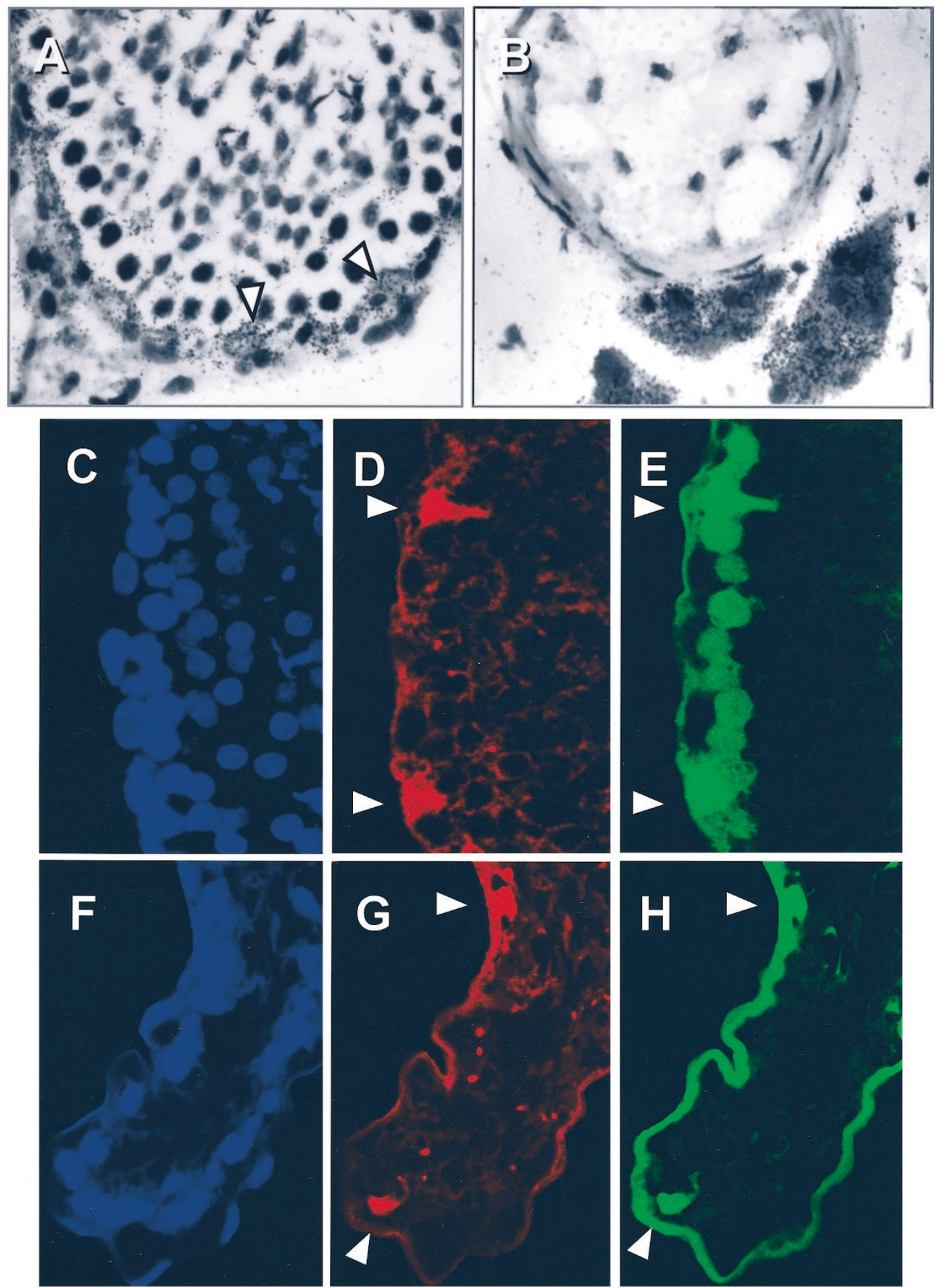

Figure 4.

Analysis of gap junctional coupling in seminiferous tubules with normal spermatogenesis or with characteristics of SCO syndrome in a rat model. A, In the testis with normal spermatogenesis, Cx43 mRNA is detected within the basal compartment of seminiferous tubules mainly in Sertoli cells (arrowheads). B, The hybridization signal is impaired in seminiferous tubules with characteristics of SCO syndrome, compared with the strong interstitial labeling. 4,6-Diamidino-2-phenylindole (DAPI) staining (blue fluorescence) of seminiferous tubules with normal spermatogenesis $(C)$ and with characteristics of SCO syndrome (F). Columnar distribution of the rhodamine (red fluorescence) typical of Sertoli cells (arrowheads) in seminiferous tubules with normal spermatogenesis (D) and with characteristics of SCO syndrome (G). E, Diffusion of Lucifer yellow (green fluorescence) from Sertoli cells (arrowheads) to basally adjacent cells in seminiferous tubules with normal spermatogenesis. $\mathrm{H}$, Loss of dye-coupling between Sertoli cells in seminiferous tubules with characteristics of SCO syndrome.

identified by their specific columnar distribution of the fluorescence (Fig. 4D). Consistent with the lack of diffusion of high-molecular weight marker through gap junctions, no transfer of dextran-rhodamine could be observed between adjacent cells (Fig. 4D). In contrast, diffusion of Lucifer yellow, a low-molecular weight dye 
( $<1 \mathrm{kDa}$ ), occurred from these two injured Sertoli cells to adjacent Sertoli and to basally located germ cells (Fig. 4E). Among the double-loaded Sertoli cells identified $(n=500)$ on the 200 seminiferous tubule sections analyzed, approximately $40 \%$ exhibited Lucifer yellow coupling with neighboring Sertoli cells. The diffusion of this dye was reduced by $90 \%$ in the presence of $3 \mathrm{~mm}$ heptanol, an inhibitor of gap junctional coupling, indicating that diffusion of the Lucifer yellow was mediated by gap junction (data not shown). Conversely, in the SCO seminiferous tubules, no diffusion of Lucifer yellow occurred toward adjacent Sertoli cells as visualized in Figure 4, $\mathrm{G}$ and $\mathrm{H}$.

\section{Discussion}

The present study shows for the first time that minimal if any Cx43 mRNA expression was detected by in situ hybridization within the seminiferous tubules of patients with severe secretory azoospermia (SCO syndrome) compared with testes with normal spermatogenesis. Therefore, the decrease in testicular $\mathrm{C} \times 43$ mRNA level, evaluated by semiquantitative RT-PCR in testicular biopsy specimens of secretory azoospermic patients, probably reflects the decrease of this transcript within the seminiferous epithelium. Furthermore, our findings revealed a concomitant disappearance of Cx43 mRNA and protein in Sertoli cells in pathologic testes, whereas they were maintained in the interstitial tissue.

There is strong evidence that $\mathrm{Cx} 43$ gap junctions occur between Sertoli cells and that they are located in the basal compartment of the seminiferous tubules (Batias et al, 1999; Lablack et al, 1998; Risley et al, 1992). These data do not preclude that other Cx detected within the seminiferous epithelium, such as Cx26 and $\mathrm{Cx} 32$, are able to form channels with themselves or in association with Cx43 (Bruzzone et al, 1996) as suggested from the observations obtained in the xenope model. This hypothesis is, however, not sustained by the detection of Cx26 and Cx32 in the apical compartment of the seminiferous epithelium (Risley et al, 1992), compared with the basal localization of $\mathrm{Cx} 43$. Moreover, two other members of the $\mathrm{Cx}$ family, Cx31 and Cx33, have been localized in the basal compartment (Mok et al, 1999; Tan et al, 1996); but these $\mathrm{Cx}$ are unable to communicate with other $\mathrm{Cx}$ members (Chang et al, 1996; Elfgang et al, 1995). Thus, it is tempting to suggest that gap junctions that occur basally between neighboring Sertoli cells are mainly formed of $\mathrm{Cx} 43$. Several studies have revealed that Sertoli cells are coupled by gap junctions (Batias et al, 2000; Enders, 1993; Lablack et al, 1998; Risley et al, 1992) and that this coupling is nonselective of low-molecular weight tracer used (Risley et al, 2002). From the present data, it is likely that Sertoli cells, which are located within the damaged tubules, could be unable to communicate between them via $\mathrm{Cx} 43$ gap junctions. This latter hypothesis is in agreement with previous ultrastructural studies (Cavicchia et al, 1996) and is strongly supported by the current observation that in situ Lucifer yellow coupling between adjacent Sertoli cells was impaired in the seminiferous tubules of a rat model with severe alteration of spermatogenesis.

There is compelling evidence that the contingent of Sertoli cells that is present in human seminiferous tubules with spermatogenic arrest exhibit immature morphologic and physiologic characteristics, such as oval nuclei with smooth profiles, even heterochromatin distribution, a single nucleolus (Cavicchia et al, 1996), and anti-müllerian hormone and cytokeratin 18 expression (Bar-Shira et al, 2000; Steger et al, 1996). Our data show that $\mathrm{Cx} 43$ was not expressed in Sertoli cells present within seminiferous tubules with SCO syndrome characteristics. Given the essential role of Cx43 in Sertoli cell control of spermatogenesis (Juneja et al, 1999; Plum et al, 2000), its defect could reflect a new functional marker of undifferentiated Sertoli cells in the pathologic seminiferous tubules.

Impaired GJIC and loss of Cx expression have been shown to correlate with neoplastic transformation of several human tissues such as breast (Laird et al, 1999), lung (Ruch et al, 2001), brain (Soroceanu et al, 2001), endometrium (Saito et al, 2001), and prostate (Hossain et al, 1999). Testicular cancer is the most common malignancy of young men (Adami et al, 1994; Forman and Moller, 1994), and an increased risk of this cancer has been reported in the population of infertile men (Moller and Skakkebaek, 1999). Both infertility and testicular cancer progression have been suggested to be correlated with an impaired function and/or differentiation of Sertoli cells (Skakkebaek et al, 1998). Therefore, it might be possible that the lack of Cx43 expression evidenced here in Sertoli cells of infertile patients could favor testicular tumorigenesis. Further studies investigating $\mathrm{Cx} 43$ expression in tumoral tissue are necessary to assess Sertoli cell Cx43 alteration in the promotion of testicular cancer in humans.

\section{Materials and Methods}

\section{Samples}

Normal testes were obtained from 60- to 65-year-old patients undergoing orchidectomy for prostate cancer $(n=3)$. Biopsy specimens of normal testes were performed in young men (28-38 years) with excretory azoospermia caused by deferent duct agenesis ( $n=$ 8). Pathologic testicular tissues were collected by biopsies from young men with $46 \mathrm{XY}$ karyotype and presenting partial or total spermatogenesis failure related to secretory azoospermia $(n=7)$. None of the patients, who gave informed consent for this study, had received hormonal therapy or chemotherapy before the collection of tissue samples. Clinical, biologic, and histologic features of patients are indicated in Table 1.

Naturally unilateral cryptorchid Long-Evans rats were purchased at the age of 80 to 90 days from CSEAL-CNRS (Orléans, France). As previously reported by our group (Mouhadjer et al, 1989) and by others (Penson et al, 1997), seminiferous tubules from 
Table 1. Clinical, Biologic, and Histologic Features of Patients with Normal Spermatogenesis (Excretory Azoospermia) or Impaired Spermatogenesis (secretory azoospermia)

\begin{tabular}{|c|c|c|c|c|c|c|c|}
\hline \multirow{2}{*}{$\begin{array}{l}\text { Patient } \\
\text { no. }\end{array}$} & \multirow{2}{*}{$\begin{array}{c}\text { Clinical features } \\
\text { azoospermia }\end{array}$} & \multicolumn{2}{|c|}{$\begin{array}{l}\text { Testicular } \\
\text { volume (ml) }\end{array}$} & \multirow[b]{2}{*}{ FSH IU/L } & \multirow{2}{*}{$\begin{array}{c}\text { Testosterone } \\
\mu \mathrm{g} / \mathrm{L}\end{array}$} & \multirow{2}{*}{$\begin{array}{l}\text { CX43/GAPDH } \\
\text { (ROD) }\end{array}$} & \multirow[b]{2}{*}{ Histologic analysis } \\
\hline & & Right & Left & & & & \\
\hline 1 & Excretory & $>15$ & $>15$ & 3.6 & 5.8 & 0.723 & Spermatozoa \\
\hline 2 & Excretory & $>15$ & $>15$ & 4.0 & 4.6 & 4.040 & Spermatozoa \\
\hline 3 & Excretory & $>15$ & $>15$ & 7.0 & 5.9 & 0.776 & Spermatozoa \\
\hline 4 & Excretory & $>15$ & $>15$ & 5.0 & 7.2 & 2.100 & Spermatozoa \\
\hline 5 & Excretory & $>15$ & $>15$ & 4.5 & 6.8 & 1.900 & Spermatozoa \\
\hline 6 & Excretory & $>15$ & $>15$ & 3.5 & 6.3 & 0.863 & Spermatozoa \\
\hline 7 & Excretory & $>15$ & $>15$ & 4.0 & 5.6 & 1.238 & Spermatozoa \\
\hline 8 & Excretory & $>15$ & $>15$ & 6.0 & 6.1 & 1.470 & Spermatozoa \\
\hline 9 & Secretory & 12 & 12 & 13.9 & 5.6 & 0.550 & Spermatogonia \\
\hline 10 & Secretory & $>15$ & $>15$ & 20.2 & 6.1 & 0.705 & Spermatogonia \\
\hline 11 & Secretory & 12 & $<15$ & 22.0 & 4.9 & 0.365 & SCO syndrome \\
\hline 12 & Secretory & 12 & 12 & 16.1 & 4.2 & 0.382 & SCO syndrome \\
\hline 13 & Secretory & $<12$ & $>12$ & 12.0 & 5.1 & 0.365 & Spermatogonia \\
\hline 14 & Secretory & 12 & 12 & 21.0 & 4.3 & 0.354 & Spermatogonia \\
\hline 15 & Secretory & 12 & 12 & 22.0 & 6.1 & 0.204 & SCO syndrome \\
\hline
\end{tabular}

FSH, follicle stimulating hormone; ROD, relative optical density.

abdominal testis exhibited characteristics of SCO syndrome. At least three abdominal and three contralateral scrotal testes were examined.

\section{Semiquantitative RT-PCR}

Semiquantitative RT-PCR was used to compare Cx43 mRNA expression between patients with normal or altered spermatogenesis using GAPDH as an internal standard. Briefly, total RNA was extracted from testicular biopsy specimens using RNeasy (Qiagen, Courtaboeuf, France). RNA was treated with RNasefree DNase I (Life Technologies Gibco BRL, Cergy Pontoise, France) at $22^{\circ} \mathrm{C}$ for 5 minutes. RNA $(2 \mu \mathrm{g})$ was reverse transcribed into cDNAs using oligo(dT)12-18 as primer (Roche Diagnostics, Meylan, France) and SuperScriptll reverse transcriptase (Life Technologies). To confirm that there was no genomic DNA contamination within the total RNA, the RT-PCR reactions were performed under identical conditions with the exception that SuperScriptll was omitted in the cDNA synthesis step. This mixture was used as a control in subsequent PCR amplification steps. PCR was performed with an MJ Research, PTC-100 DNA thermal cycler as recommended by the supplier. Primers were designed from previously published sequence data: for GAPDH (Diez de Medina et al, 1997), 5'-CTG CAC CAC CAA CTG CTT AG-3' (sense) and 5'-AGG TCC ACC ACT GAC ACG TT-3' (antisense); and for Cx43 (Pozzi et al, 1995), 5'-AGT CTA TCT TTG AGG TGG CC-3' (sense) and 5'-GGC TGT AAT TCA TGT CCA GC-3' (antisense). The cycling parameters for the PCR reaction were as follows: denaturation at $94^{\circ} \mathrm{C}$ for 1 minute, annealing at $60^{\circ} \mathrm{C}$ for 1 minute, and elongation at $72^{\circ} \mathrm{C}$ for 1 minute, for a total of 27 cycles. PCR products were run on $1.5 \%$ agarose gel (Eurobio, Les Ulis, France), stained with ethidium bromide, and photographed with Polaroid film. The sizes of the expected amplification products are 1158 bp for Cx43 and $275 \mathrm{bp}$ for GAPDH. The identity of the product was determined by sequencing. The amount of amplified products was quantified using the Image Master VDS and the Image Master 1D Software Version 3.00 (Amersham Pharmacia Biotech, Orsay, France). Each value was determined as the mean of three densitometry readings. Results are expressed as the average ratios of the relative optical densities of Cx43 PCR product to those of GAPDH. The nonparametric Mann-Whitney $U$ test was used for comparison between the two groups of patients. The level of significance is as given in legend to Figure 1.

\section{In Situ Hybridization}

In situ hybridization was performed as previously described (Batias et al, 2000). The radiolabeled probes were generated by in vitro transcription and incorporation of $\left[{ }^{35}\right.$ S] uridine triphosphate (specific ratio activity, $1000 \mathrm{Ci} / \mathrm{mmol}$; Amersham, Buckinghamshire, United Kingdom). Testicular tissue was fixed by immersion in $4 \%$ paraformaldehyde in PBS $(\mathrm{pH} 7.4)$ during 16 hours at $4^{\circ} \mathrm{C}$. For each sample, two serial sections were mounted on the same histologic slide. One received the antisense RNA probe, and the other received the RNA sense probe as background control. After posthybridization washings, the slides were dipped in NTB2 emulsion (Kodak, Rochester, NY) and exposed at $4^{\circ} \mathrm{C}$ in lightness boxes for 21 days. Slides were developed, fixed, and counterstained with toluidine blue. Approximately 10 seminiferous tubules from 3 different sections for each normal or pathologic testis were examined by two observers, who selected representative areas to be photographed. Hybridization intensity was quantified using a computer- 
assisted image analysis system (Visilog 4.15; Noesis, Les Ulis, France), consisting of an IMC 500 camera and an IMC 500 digitizer (Batias et al, 2000). The intensity of hybridization was expressed as percentage of pixels within a marked area occupied by silver grains that was above a set gray threshold level. Measurements were taken from 10 seminiferous tubules from 3 different sections for each testis. A one-way ANOVA followed by a Student-NewmanKeuls post-hoc test was used to test for differences between cells. Values were considered statistically different when $p<0.05$.

\section{Immunohistochemistry}

Fresh testis pieces were cut with a razor blade, embedded in OCT embedding compound (Tissue Tek), and stored at $-80^{\circ} \mathrm{C}$. Cryosections $(5 \mu \mathrm{m})$ were mounted on 3-aminopropytriethoxysilane-coated slides and then stored at $-80^{\circ} \mathrm{C}$. The integrity of spermatogenesis was examined by classical histologic procedures by fixing a piece of each testis in aqueous Bouin. Immunohistochemical localization of Cx43 was performed using a K 680 Kit (Dako, Trappes, France). Briefly testicular sections were incubated in a $3 \% \mathrm{H}_{2} \mathrm{O}_{2}$ solution for 30 minutes to inhibit endogenous peroxidase activity. Sections were washed in PBS, exposed to the blocking reagent for 1 hour at room temperature, and incubated overnight at $4^{\circ} \mathrm{C}$ with the anti-Cx43 antibody (Transduction Laboratories, Lexington, Kentucky) diluted 1/200 in PBS containing $3 \%$ BSA. Sections were incubated for 30 minutes with a secondary biotinylated anti-mouse antibody, washed in PBS-0.1\% Tween, and exposed to peroxidase streptavidin for 30 minutes. After washing, testis sections were then incubated for 10 minutes in the substrate solution 3-amino-9-ethylcarbazol. Slides were counterstained in hemalun for 1 minute and washed in tap water. As a negative control, adjacent tissue sections were processed by omission or by replacing the primary antibody with nonimmune IgG diluted 1/200.

\section{In Situ Dye-Coupling}

Cell-to-cell coupling in seminiferous tubules was measured by the cut-end loading method originally described by Tsien and Weingart (1976) and modified by our group (Batias et al, 2000). Briefly, pieces of scrotal and abdominal testes from LE-ORL rats were cut and incubated for 10 minutes at $32^{\circ} \mathrm{C}$ in PBS containing $0.5 \%$ (w/v) Lucifer yellow (molecular weight: 475.2; Sigma, St. Louis, Missouri) and 0.5\% (w/v) dextran coupled to rhodamine (molecular weight: 10,000; Sigma) which was used as a negative control. Testis pieces were rinsed in PBS, fixed in $4 \%$ paraformaldehyde for 48 hours, and then embedded by standard paraffin procedure. Sections $(5 \mu \mathrm{m})$ were performed in plane perpendicular to that of the razor blade cutting and incubated for 1 minute with DAPI $(2 \mu \mathrm{g} / \mathrm{ml})$ to stain nuclei. Approximately 200 sections from 3 scrotal testes and 3 controlateral abdominal testes were examined by fluorescence microscopy. Sections in which Sertoli cells injured by cutting were loaded with both Lucifer yellow and dextran-rhodamine were selected, and adjacent Sertoli cells loaded with Lucifer yellow were counted.

\section{Acknowledgements}

We thank Drs. J.-M. Gasc and M.-T. Morin for their help in in situ hybridization experiments, Mr. J. M. Lepecq for photographic illustrations, and Ms. A. Triclin for her technical assistance.

\section{References}

Adami HO, Bergstrom R, Mohner M, Zatonsky W, Storm H, Ekbom A, Tretly S, Teppo L, Ziegler H, and Rahu M (1994). Testicular cancer in nine northern European countries. Int $J$ Cancer 59:33-38.

Bar-Shira MB, Paz G, Elliott DJ, Hammel I, Kleiman SE, Yogev L, Hauser R, Botchan A, and Yavetz H (2000). Maturation phenotype of Sertoli cells in testicular biopsies of azoospermic men. Hum Reprod 15:1537-1542.

Batias C, Defamie N, Lablack A, Thepot D, Fenichel P, Segretain D, and Pointis G (1999). Modified expression of testicular gap-junction connexin 43 during normal spermatogenic cycle and in altered spermatogenesis. Cell Tissue Res 298:113-121.

Batias C, Siffroi JP, Fénichel P, Pointis G, and Segretain D (2000). Connexin43 gene expression and regulation in the rodent seminiferous epithelium. J Histochem Cytochem 48: 793-805.

Bigliardi E and Vegni-Talluri M (1977). Gap junctions between Sertoli cells in the infertile human testis. Fertil Steril 28:755758.

Bruzzone R, White TW, and Paul DL (1996). Connections with connexins: The molecular basis of direct intercellular signaling. Eur J Biochem 238:1-27.

Cavicchia JC, Sacerdote FL, and Ortiz L (1996). The human blood-testis barrier in impaired spermatogenesis. Ultrastruct Pathol 20:211-218.

Chang M, Werner R, and Dahl G (1996). A role for an inhibitory connexin in testis? Dev Biol 175:50-56.

Diez de Medina SG, Chopin D, El Marjou A, Delouvee A, Larochelle WJ, Hoznek A, Abbou C, Aaronson SA, Thierry JP, and Radvanyi F (1997). Decreased expression of keratinocyte growth factor receptor in a subset of human transitional cell bladder carcinomas. Oncogene 14:323-330.

Elfgang $\mathrm{C}$, Eckert $\mathrm{R}$, Lichtenberg-Frate $\mathrm{H}$, Butterweck $\mathrm{A}$, Traub O, Klein RA, Hulser DF, and Willecke K (1995). Specific permeability and selective formation of gap junction channels in connexin-transfected HeLa cells. J Cell Biol 129:805-817.

Enders GC (1993). Sertoli-Sertoli and Sertoli-germ cell communication. In: Russel LD and Griswold MD, editors. The Sertoli cell. Clearwater: Cache River Press, 448-460.

Forman D and Moller H (1994). Testicular cancer. Cancer Surv 19-20:323-341.

Goodenough DA, Goliger JA, and Paul DL (1996). Connexins, connexons, and intercellular communication. Annu Rev Biochem 65:475-502. 
Hossain MZ, Jagdale AB, Ao P, LeCiel C, Huang RP, and Boynton AL (1999). Impaired expression and posttranslational processing of connexin 43 and down regulation of gap junctional communication in neoplastic human prostate cells. Prostate 38:55-59.

Juneja SC, Barr KJ, Enders GC, and Kidder GM (1999). Defects in the germ line and gonads of mice lacking connexin43. Biol Reprod 60:1263-1270.

Kumar NM and Gilula NB (1996). The gap junction communication channel. Cell 84:381-388.

Lablack A, Bourdon V, Defamie N, Batias C, Mesnil M, Fenichel P, Pointis G, and Segretain D (1998). Ultrastructural and biochemical evidence for gap junction and connexin 43 expressions in a clonal Sertoli cell line: A potential model in the study of junctional complex. Cell Tissue Res 294:279287.

Laird DW, Fistouris P, Batist G, Alpert L, Huynh HT, Carystinos GD, and Alaoui-Jamali MA (1999). Deficiency of connexin43 gap junctions is an independent marker for breast tumors. Cancer Res 59:4104-4110.

Mok BW, Yeung WS, and Luk JM (1999). Differential expression of gap-junction gene connexin 31 in seminiferous epithelium of rat testes. FEBS Lett 453:243-248.

Moller H and Skakkebaek NE (1999). Risk of testicular cancer in subfertile men: Case-control study. BMJ 318:559-562.

Mouhadjer N, Pointis G, Malassiné A, and Bedin M (1989). Testicular steroid sulfatase in a cryptorchid rat strain. J Steroid Biochem 34:555-558.

Nagano T and Susuki F (1976). Freeze-fracture observations on the intercellular junctions of Sertoli cells and of Leydig cells in the human testis. Cell Tiss Res 166:37-48.

Omori Y, Zaidan Dagli ML, Yamakage K, and Yamasaki H (2001). Involvement of gap junctions in tumor suppression: Analysis of genetically-manipulated mice. Mutat Res 477: 191-196.

Penson DF, Lugg JA, Coyne C, Sadeghi F, Freedman AL, Gonzalez-Cadavid NF, and Rajfer J (1997). Effect of cryptorchidism on testicular histology in a naturally cryptorchid animal model. J Urol 158:1978-1982.

Plum A, Hallas G, Magin T, Dombrowski F, Hagendorff A, Schumacher B, Wolpert C, Kim JS, Lamers WH, Evert M, Meda P, Straub O, and Willecke K (2000). Unique and shared functions of different connexins in mice. Curr Biol 10:10831091.

Pozzi A, Risek B, Kiang DT, Gilula NB, and Kumar NM (1995). Analysis of multiple gap junction gene products in the rodent and human mammary gland. Exp Cell Res 220:212-219.
Risley MS, Tan IP, and Farrell J (2002). Gap junctions with varied permeability properties establish cell-type specific communication pathways in the rat seminiferous epithelium. Biol Reprod 67:945-952.

Risley MS, Tan IP, Roy C, and Saez JC (1992). Cell-, age- and stage-dependent distribution of connexin43 gap junctions in testes. J Cell Sci 103:81-96.

Ruch RJ, Porter S, Koffler LD, Dwyer-Nield LD, and Malkinson AM (2001). Defective gap junctional intercellular communication in lung cancer: Loss of an important mediator of tissue homeostasis and phenotypic regulation. Exp Lung Res 27:231-243.

Saito T, Nishimura M, Kudo R, and Yamasaki H (2001). Suppressed gap junctional intercellular communication in carcinogenesis of endometrium. Int J Cancer 93:317-323.

Skakkebaek NE, Rajpert-De Meyts E, Jorgensen N, Carlsen E, Petersen PM, Giwercman A, Andersen G, Jensen TK, Andersson A-M, and Müller J (1998). Germ cell cancer and disorders of spermatogenesis: An environmental connection? In: Rajpert-De Meyts E, Grigor KM, and Skakkebaek $\mathrm{NE}$, editors. Neoplastic transformation of testicular germ cells. Copenhagen: Munksgaard, 3-12.

Soroceanu L, Manning TJ Jr, and Sontheimer H (2001). Reduced expression of connexin-43 and functional gap junction coupling in human gliomas. Glia 33:107-117.

Steger K, Rey R, Kliesch S, Louis F, Schleicher G, and Bergmann M (1996). Immunohistochemical detection of immature Sertoli cell markers in testicular tissue of infertile adult men: A preliminary study. Int J Androl 19:122-128.

Steger K, Tetens F, and Bergmann M (1999). Expression of connexin 43 in human testis. Histochem Cell Biol 112:215220.

Tan IP, Roy C, Saez JC, Saez CG, Paul DL, and Risley MS (1996). Regulated assembly of connexin33 and connexin43 into rat Sertoli cell gap junctions. Biol Reprod 54:1300-1310.

Trosko JE and Ruch RJ (1998). Cell-cell communication in carcinogenesis. Front Biosci 3:D208-D236.

Tsien RW and Weingart R (1976). Inotropic effect of cyclic AMP in calf ventricular muscle studied by a cut end method. J Physiol 260:117-141.

White TW and Paul DL (1999). Genetic diseases and gene knockouts reveal diverse connexin functions. Ann Rev Physiol 61:283-310. 